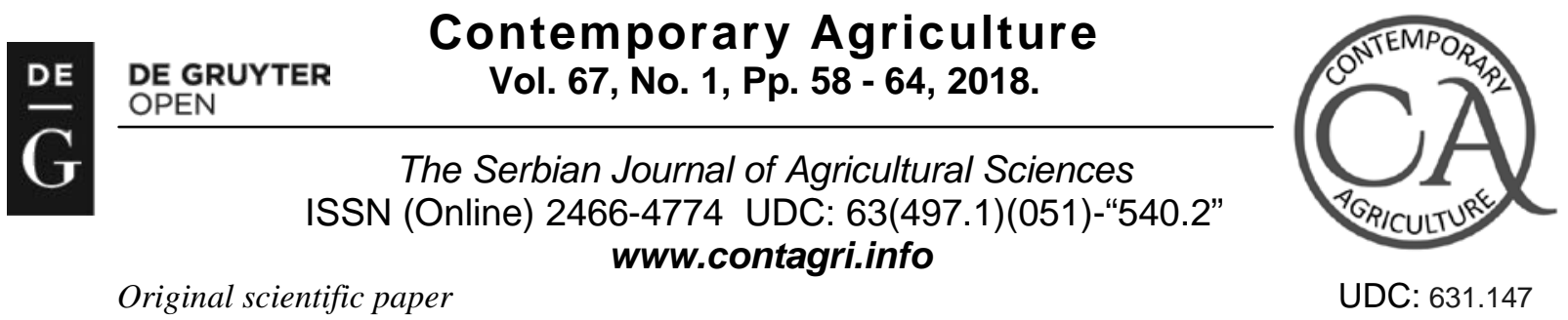

DOI: 10.2478/contagri-2018-0009

\title{
THE IMPACT OF ORGANIC AGRICULTURE ON BIODIVERSITY CONSERVATION AND MILK QUALITY FOR TRADITIONAL CHEESE PRODUCTION
}

\author{
Anka POPOVIĆ-VRANJEŠ ${ }^{\star 1}$, Snežana PASKAŠ ${ }^{1}$, Zsolt BECSKEI², Marija JEVTIĆ ${ }^{3}$, Saša \\ KRSTOVIĆ
}

\begin{abstract}
Summary: Organic farming represents agricultural practice that could contribute to the preservation of biological diversity and breeding of cows with the most desired milk quality attributes. Milk composition could vary widely according to genetic diversity of the animals and different feeding systems. These are related to higher dry matter content, fat, protein and a more favorable ratio of the saturated / unsaturated fatty acids, which is important in traditional cheese production. Standard chemical analyzes were performed and this paper shows the differences in the chemical properties and the fatty acid profile of milk, depending on the different breeds and breeding methods of animals. Simmental milk (indoors) was most abundant in dry matter and fat (13.01 and 4.30\%, respectively) while protein and casein level was the highest in the Busha milk (3.67 and 2.63\%, respectively). Holstein Friesian milk (organic) possessed a more constant composition and, together with Busha appropriate hygienic quality of milk (low level of somatic cells and total bacteria count). Also, milk from Holstein Friesian cows (organic) was disposed with better nutritional quality and more desirable fatty acid profile (SFA (63.40\%), MUFA (30.79\%) and PUFA (5.72 \%)). On the other hand, Holstein Friesian (conventional) milk contained SFA (67.45\%), MUFA (29.27\%) and PUFA (3.28\%) while Simmental (indoors) higher values of SFA (71.21\%) and less MUFA (25.39\%) and PUFA (3.40\%). There are various ways to preserve biodiversity and the application of organic production standards in the traditional cheese production contributes to obtaining safer, quality products which are more recognizable on the market.
\end{abstract}

Key words: biodiversity, organic agriculture, breeds, milk quality, cheese

\section{INTRODUCTION}

There is an increasing awareness of the high levels of biodiversity and the important role it plays in enhancing the sustainability of low-input dairy production systems. Conventional agro ecosystems are poor in biodiversity and significantly contributed to the reduced number of breeds and genetic diversity of domestic animals. Although, adopted numerous acts and measures to protect autochthonous breeds and genetic resources, many are still facing the threat of the complete disappearance. The available data indicate that genetic erosion has continued over the 2006 to 2014 period, with the proportion of breeds falling into the at-risk category increasing, relative both to the total number of recorded breeds and to the number for which population data are available. However, the full picture of the status and trends of breed risk remains to a large degree obscured by gaps in current and historical data on breed population sizes (FAO, 2015). Sustainable farming systems such as organic farming are now seen by many as a potential solution to this continued loss of biodiversity and receive substantial support in the form of subsidy payments through EU and national government legislation (Hole et al., 2005). Organic animal husbandry has a favorable effect on agro-biodiversity (races used by farmers) and natural biodiversity (wild species). It can contribute to the conservation and protection of numerous animals (Mondelaers et al., 2009). Greater biodiversity in organic systems was also reported by Rahmann (2011) and Niggli et al. (2008). The milk of some breeds are ideal for liquid milk and cream but not for cheese making. Breed is the main genetic factor affecting the milk quality characteristics

${ }^{1}$ Anka Popović-Vranješ, PhD, Full Professor, Snežana Paskaš, Mr, Research Associate, Saša Krstović, DVM, Research Associate, University of Novi Sad, Faculty of Agriculture, Trg Dositeja Obradovića 8, 21000 Novi Sad, Serbia.

${ }^{2}$ Zsolt Becskei, PhD, Teaching Assistant, University of Belgrade, Faculty of Veterinary Medicine, Bulevar Oslobodjenja 18, 11000 Belgrade, Serbia.

${ }^{3}$ Marija Jevtić, PhD, Full Professor, University of Novi Sad, Faculty of Medicine, Hajduk Veljkova 3, 21000 Novi Sad, Serbia.

•Corresponding author: Anka Popović-Vranješ, e-mail: anka.popovic@gmail.com, Tel.:+38121 4853372 
that influence individuality of some cheeses and more rapid coagulation of milk (Eenennaam and Medrano, 1991). In traditional cheese production is very important content of milk fat, protein and lactose as well as their ratio and proportion of the $\kappa$-casein protein. The $\beta$ variants of $\mathrm{k}$-casein have been associated with increased cheese yield for two reasons. One is the increased casein content of milk and the other is a possible increase in free calcium which produces a firmer rennet curd (Eenennaam and Medrano, 1991). The milk composition, which is influenced by the breed of cow, has the greatest effect on the cheese yield capacity of milk (Lawrence, 1991) and differences in milk clotting properties various among breeds (Auldist et al., 2004). Although Holstein Friesians (HF) produces a high volume of milk their milk has a fair quality for cheese making because of lower milk protein content (De Marchi et al., 2007). In other hand, Holsteins are the most efficient breed in producing large volumes of milk and constant level levels of milk fat and protein, and it will remain the prominent breed for producing low cost commodity cheeses (Auldist et al., 2004). On other hand, autochthonous breeds do not produce a large volume of milk, but they have good quality milk which has contain desirable protein to fat ratio and small globules of fat that are more naturally homogenized. Besides, autochthonous breeds are an integral part of the ecosystem and represent unique gene combinations. The breed appears to be a subtle combination of biology and culture, adapted to specific needs and conditions (Berarad and Marcheay, 2006). Local breeds are becoming more and more important in the designations of the origins of cheeses. In Europe there are a rising number of examples where demand for regionally typical food products has turned the conservation of local breeds into a commercially viable undertaking (Köhler-Rollefson, 2001). The cheese-making systems unite countless practices and forms of knowledge from all domains of living organisms, including plants, animals, and micro-organisms. The type of milk used for cheese production can be critical when it comes to cheeses with protected geographic indication (De Marchi et al, 2008). Protecting local products means conserving varied local ecosystems at various levels: animals, plants (breeds and local varieties), plant associations, microbial ecosystems, including the places for maturing cheeses and the landscape (Berard and Marchenay, 2006). In Serbia, Busha autochthonous breed survives in small, highly endangered, populations. The breed is hardy and well-suited to extensive farming, but has relatively low production yields. It is an important part of the local identity, but will be lost if conservation measures are not put in place to protect it (FAO, 2015). There are many other influences on the quality of the milk, however, not just the breed (for example, feeding, the climate, seasonal changes, stage of lactation, animal health, herd management routines, etc). The influence of animal feed on milk composition has been, and continues to be, the focus of many studies. Milk can be modified to improve it nutrient value and sensory quality by changing the animal's diet (Wiking et al., 2010). Dairy product safety is an additional concern related to milk quality (Ruegg, 2003). Milk quality is usually defined by the somatic cell count (SCC) and the bacterial count. High SCC milk reduces the shelf life of dairy products and diminishes the quality and quantity of milk protein, thereby reducing cheese yields (Barbano et al., 1991).

Milk fatty acids (FA) composition has a number of effects on milk quality, including its physical as well as nutritional properties. FA composition also affects the organoleptic properties due to factors such as the effects of free short-chain FA and oxidative changes in FA (Chilliard et al., 2001). Based on few studies, essentially conducted to isolate some feeding effect, the breed seemed to influence the fatty acids composition. Available results showed the existence of breed effects (Soyeurt and Gengler, 2008). Comparative studies seem to indicate that dairy breeds with a high milk fat content often have a less desirable milk fat composition (higher levels of saturated and hypercholesterolaemic fatty acids, and a lower proportion of polyunsaturated fatty acids) than breeds with a lower milk yield or fat content. The fat composition produced by indigenous breeds, dual-purpose breeds and crossbreds appears to have a more desirable profile than imported dairy breeds (mostly Holstein) (Samkova et al., 2012).

The aims of the present study were to examine the impact of production practices of organic agriculture on a milk quality for cheese production. Furthermore, were investigated chemical properties and the fatty acids profile of milk, depending on the different breeds and breeding methods of animals in terms of their suitability for cheese production.

\section{MATERIAL AND METHODS}

The paper considers milk from four different cow breeds. Milk samples were collected from the commercial and organic Holstein-Friesian (HF) farms $(n=5)$. Furthermore, milk samples $(n=5)$ of Simmental cattle and Simmental farms that could be categorized into two different systems of production (breeding cows indoors and outdoors) were analyzed. Finally, milk of Domestic Spotted cattle (outdoors) $(n=5)$ and Busha cattle $(n=5)$ were also analyzed. Samples were taken between March and July 2017.

Standard analyses of the chemical milk composition were done with the MilkoScan FT + analyzer using the FTIR technique. MilkoScanTM + FT techniques were in accordance with ISO 9622 / IDF 141: 2013 and AOAC official methods 972.16. For the determination of somatic cells in raw milk FossomaticFT FC (ISO 13366-2) was 
used, and for a total number of bacteria BactoScanTM FC + (ISO 16297). Determination of the free fatty acid (FA) in the cheese was done after methylation with borontrifluoride in methanol, using Shimadzu's gas chromatograph with flame ionization detector (FID) on InterCap WAX (length $30 \mathrm{~m}$, inner diameter $0.25 \mathrm{~mm}$, film thickness 0.25 $\mu \mathrm{m})$ column (AOAC 996.06).

The obtained results of milk were analyzed using Microsoft Excel 10 and showed as arithmetic mean, standard deviation and coefficient of variation.

\section{RESULTS}

A number of differences were identified in chemical milk composition due to different breeds and production system (Table 1.). The obtained results showed that higher levels of desirable compounds for cheese production found in the Simmental milk (indoors), which average contain $13.01 \%$ of dry matter and $4.30 \%$ of milk fat. The lowest content of these components was found in HF milk (conventional) (12.06 and $3.50 \%$, respectively). Contrary to conventional production HF milk from organic production contained higher amount of these compounds (12.83 and $3.97 \%$, respectively). The most sensitive component of milk was milk fat which also affected the casein/fat (C/F) ratio. The highest coefficients of variation possessed Busha and HF milk (conventional) (CV, 14.01\% and $10.29 \%$, respectively) while HF milk (organic) and Simmental milk (indoors) had similar results (CV, 3.27 and $3.49 \%$, respectively). Milk from autochthonous Busha cattle breed was abundant with protein and casein (3.67 and $2.63 \%$, respectively) and from this point very suitable for cheese production. Ideal C/F ratio is different for different type of cheese which is amounts for whole milk cheeses 0.7. All milk samples possessed similar results (ranged from 0.64 to 0.67 ), except Simmental (indoors) which recorded value of 0.52 and Busha 0.74 .

Table 1. Chemical composition of milk (4 different breeds and breeding methods)

\begin{tabular}{|c|c|c|c|c|c|c|c|c|c|c|c|c|}
\hline \multirow[t]{2}{*}{ Parameters } & \multicolumn{2}{|c|}{$\begin{array}{c}\text { Holstein } \\
\text { Friesians } \\
\text { (conventional) }\end{array}$} & \multicolumn{2}{|c|}{$\begin{array}{l}\text { Holstein } \\
\text { Friesians } \\
\text { (organic) }\end{array}$} & \multicolumn{2}{|c|}{$\begin{array}{l}\text { Simmental } \\
\text { (outdoors) }\end{array}$} & \multicolumn{2}{|c|}{$\begin{array}{c}\text { Simmental } \\
\text { (indoors) }\end{array}$} & \multicolumn{2}{|c|}{$\begin{array}{c}\text { Domestic } \\
\text { spotted cattle } \\
\text { (outdoors) }\end{array}$} & \multicolumn{2}{|c|}{ Busha } \\
\hline & $\bar{x} \pm \mathrm{SD}$ & $\begin{array}{l}\text { CV } \\
(\%)\end{array}$ & $\bar{x} \pm \mathrm{SD}$ & $\begin{array}{l}\text { CV } \\
(\%)\end{array}$ & $\bar{x} \pm \mathrm{SD}$ & $\begin{array}{l}\text { CV } \\
(\%)\end{array}$ & $\bar{x} \pm \mathrm{SD}$ & $\begin{array}{l}\text { CV } \\
(\%)\end{array}$ & $\bar{x} \pm \mathrm{SD}$ & $\begin{array}{l}\text { CV } \\
(\%)\end{array}$ & $\bar{x} \pm \mathrm{SD}$ & $\begin{array}{l}\text { CV } \\
(\%)\end{array}$ \\
\hline $\begin{array}{l}\text { Dry matter } \\
(\%)\end{array}$ & $\begin{array}{l}12.06 \\
\pm 0.49\end{array}$ & 4.06 & $\begin{array}{l}12.83 \\
\pm 0.16\end{array}$ & 1.25 & $\begin{array}{l}12.56 \\
\pm 0.37\end{array}$ & 2.95 & $\begin{array}{l}13.01 \\
\pm 0.12 \\
\end{array}$ & 0.92 & $\begin{array}{l}12.20 \\
\pm 0.12\end{array}$ & 0.98 & $\begin{array}{l}12.71 \\
\pm 0.58\end{array}$ & 4.56 \\
\hline $\begin{array}{l}\text { Dry matter } \\
\text { non fat }(\%)\end{array}$ & $\begin{array}{c}8.57 \\
\pm 0.18\end{array}$ & 2.10 & $\begin{array}{c}8.87 \\
\pm 0.04\end{array}$ & 0.45 & $\begin{array}{c}8.77 \\
\pm 0.25\end{array}$ & 2.85 & $\begin{array}{c}8.71 \\
\pm 0.11\end{array}$ & 1.26 & $\begin{array}{c}8.54 \\
\pm 0.22\end{array}$ & 2.58 & $\begin{array}{c}9.17 \\
\pm 0.04\end{array}$ & 0.44 \\
\hline $\begin{array}{l}\text { Milk fat } \\
(\%)\end{array}$ & $\begin{array}{c}3.50 \\
\pm 0.36\end{array}$ & 10.29 & $\begin{array}{c}3.97 \\
\pm 0.13\end{array}$ & 3.27 & $\begin{array}{c}3.82 \\
\pm 0.37\end{array}$ & 9.68 & $\begin{array}{c}4.30 \\
\pm 0.15\end{array}$ & 3.49 & $\begin{array}{c}3.68 \\
\pm 0.27\end{array}$ & 7.34 & $\begin{array}{c}3.57 \\
\pm 0.50\end{array}$ & 14.01 \\
\hline $\begin{array}{l}\text { Milk } \\
\text { protein (\%) }\end{array}$ & $\begin{array}{c}3.11 \\
\pm 0.19\end{array}$ & 6.11 & $\begin{array}{c}3.35 \\
\pm 0.04\end{array}$ & 1.19 & $\begin{array}{c}3.28 \\
\pm 0.19\end{array}$ & 5.79 & $\begin{array}{c}3.01 \\
\pm 0.14\end{array}$ & 4.65 & $\begin{array}{c}3.12 \\
\pm 0.04\end{array}$ & 1.28 & $\begin{array}{c}3.67 \\
\pm 0.11\end{array}$ & 2.99 \\
\hline Casein (\%) & $\begin{array}{c}2.35 \\
\pm 0.14 \\
\end{array}$ & 5.96 & $\begin{array}{c}2.57 \\
\pm 0.04 \\
\end{array}$ & 1.56 & $\begin{array}{c}2.51 \\
\pm 0.17 \\
\end{array}$ & 6.77 & $\begin{array}{c}2.24 \\
\pm 0.08 \\
\end{array}$ & 3.57 & $\begin{array}{c}2.36 \\
\pm 0.05 \\
\end{array}$ & 2.12 & $\begin{array}{c}2.63 \\
\pm 0.10 \\
\end{array}$ & 3.80 \\
\hline $\begin{array}{l}\text { Casein/Fat } \\
(\mathrm{C} / \mathrm{F})\end{array}$ & $\begin{array}{c}0.67 \\
\pm 0.05\end{array}$ & 7.46 & $\begin{array}{c}0.65 \\
\pm 0.02 \\
\end{array}$ & 3.08 & $\begin{array}{c}0.66 \\
\pm 0.08\end{array}$ & 12.12 & $\begin{array}{c}0.52 \\
\pm 0.04\end{array}$ & 7.69 & $\begin{array}{c}0.64 \\
\pm 0.05\end{array}$ & 7.81 & $\begin{array}{c}0.74 \\
\pm 0.08\end{array}$ & 10.81 \\
\hline $\begin{array}{l}\text { Lactose } \\
(\%)\end{array}$ & $\begin{array}{c}4.75 \\
\pm 0.20\end{array}$ & 4.21 & $\begin{array}{c}4.96 \\
\pm 0.02\end{array}$ & 0.40 & $\begin{array}{c}4.81 \\
\pm 0.13\end{array}$ & 2.70 & $\begin{array}{c}5.06 \\
\pm 0.06\end{array}$ & 1.18 & $\begin{array}{c}4.82 \\
\pm 0.20\end{array}$ & 4.15 & $\begin{array}{c}5.04 \\
\pm 0.16\end{array}$ & 3.17 \\
\hline
\end{tabular}

Results related to the hygienic parameters of milk (somatic cell count (SCC) and total bacteria count (CFU)) are showed with Figure 1. The high content of SCC and CFU indicated of poor hygienic milk and the milk obtained from cows that were on pasture (Simmental and Domestic spotted cattle) had the poorest hygienic quality. Total bacteria count showed similar results for both, Simmental indoors and outdoors. According to current Serbian Legislation (2009) milk obtained from Busha and HF (organic) was in accordance with standards and indicated on hygienic milking and healthy animals. HF (conventional) presented a higher increase in SCC and CFU when compared with HF (organic). 


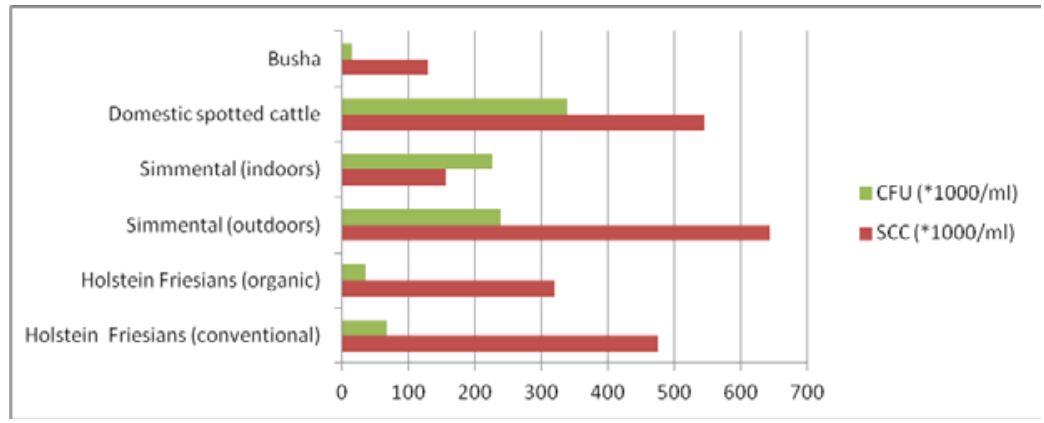

Figure. 1. Hygienic parameters of milk (mean value)

The fatty acid composition in cheese depends on the milk fat composition and the cheese making process does not modify the composition original present in milk fat. The milk fat saturated fatty acids (SFAs) concentration from the milk of Simmental cows (indoors) (71.21\%) was higher than that from HF (conventional) $(67.45 \%)$ and HF (organic) (63.49 \%) cows (Table 2). The amount of monounsaturated fatty acids (MUFAs) ranged from $25.39 \%$ (Simmental) to $30.79 \%$ (HF, organic). The concentration of polyunsaturated fatty acids (PUFAs) in HF (organic) milk fat (5.72\%) was higher than the Simmental (indoors) (3.40\%) and HF (conventional) (3.28\%). The data showed that the most nutritionally beneficial fatty acids are found in organic HF milk.

Table 2. Milk fatty acid profile (2 breeds and 3 breeding methods)

\begin{tabular}{|l|c|c|c|c|c|c|c|c|c|}
\hline \multirow{2}{*}{ Parametres } & \multicolumn{3}{|c|}{ Holstein Friesian (organic) } & \multicolumn{2}{|c|}{ Holstein Friesian (conventional) } & \multicolumn{3}{|c|}{ Simmental milk (indoors) } \\
\cline { 2 - 10 } & $\bar{x}$ & SD & $\%$ & $\bar{x}$ & SD & $\%$ & $\bar{x}$ & SD & $\%$ \\
\hline SSCFA & 1.46 & 0.95 & 3.14 & 1.27 & 0.19 & 2.83 & 2.67 & 0.51 & 6.19 \\
\hline SMCFA & 4.77 & 3.75 & 15.36 & 4.86 & 0.31 & 16.24 & 5.41 & 0.83 & 18.82 \\
\hline SLCFA & 16.39 & 0.32 & 44.99 & 14.50 & 0.73 & 48.38 & 13.28 & 0.66 & 46.20 \\
\hline SFA & & & $\mathbf{6 3 . 4 9}$ & & & $\mathbf{6 7 . 4 5}$ & & & $\mathbf{7 1 . 2 1}$ \\
\hline MUFA & 28.70 & 2.71 & $\mathbf{3 0 . 7 9}$ & 26.31 & 1.33 & $\mathbf{2 9 . 2 7}$ & 21.90 & 3.71 & $\mathbf{2 5 . 3 9}$ \\
\hline PUFA & 2.66 & 0.97 & $\mathbf{5 . 7 2}$ & 1.48 & 0.16 & $\mathbf{3 . 2 8}$ & 1.47 & 0.42 & $\mathbf{3 . 4 0}$ \\
\hline
\end{tabular}

SSCFA saturated short-chain fatty acids (C4:0, C8:0) SMCFA saturated medium- chain fatty acids (C10:0, C12:0, C14:0, ) SLCFA saturated long-chain fatty acids (C16:0, C18:0, C20:0) *SFA (sum) saturated fatty acids MUFA monounsaturated fatty acids (C18:1) PUFA polyunsaturated fatty acids (C18:2, C 18:3)

\section{DISCUSSION}

Milk quality depends of many factors and each component of milk affect cheese yield and quality. Higher levels of dry matter, milk fat and protein in HF organic milk in comparison to HF conventional milk probably was caused by different concept of feeding where high levels of silage maize and concentrate in the diet of conventional HF reduced their levels. The milk fat and protein are more responsible to diet while lactose content is difficult to be manipulated by dietary changes. The fat is a milk component which mostly varies and the percentage of fatty acids originating from an animal's meal can be over 50\% (German and Dillard, 2006). Investigated the effect of breed, herd within breed, month of lactation, protein and fat percentages, somatic cell score, titratable acidity, and log bacterial count within breed on milk coagulation properties De Marchi et al. (2007) concluded that breed was the most important source of variation and that HF breed had the worst coagulation properties. Low casein to fat ratio leads to poor cheese yield and cheese makers often reports deficient in total protein for cheese making. Therefore, a change in a cow's diet that increases component percentages, but also reduces milk yield, improvements in milk quality relate directly to improved production efficiency. Generally, milks with lower C/F ratios are favored for bloomy rind cheeses while milks with higher C/F ratios are favored for aged hard cheeses (Ehlers and Hurt, 2008). The milk quality criteria requested by milk processors or by customers of milk processing outlets are becoming more strict and rigorous. Perez (2011) claimed that the productive system had a remarkable effect on the protein percentage, SCC and fat percentage in milk and a tendency with CFU. Similarly, Quist et al. (2008) mentioned that the knowledge of the variability in the fat and protein percentages, as well as in SCC is relevant in the decision making of program management in milk production. Contrary to our results, Decante (2002) in terms of SCC, 
analyzed milk samples from 264 organic farms and compared them with the results of milk from intensive production, the obtained numbers were similar and did not show significant differences in milk quality.

Because of the greater sensitivity of milk fat to dietary manipulation than either protein or lactose, nutritional control of milk fat content and fatty acid composition received a great deal of attention and nutritional control of milk fatty acid profile has received considerable attention over the last $25 \mathrm{yr}$ (Jenkins and McGuire, 2006). The ratio of saturated and unsaturated fatty acids is very important in human nutrition and in our results milk from organic production possessed more favorable fatty acids profile. Although it is known that the nutrition of the cow affects the composition of the milk details of metabolic fat processes that determine milk fat profiles are not completely predictable. It is widely recognized that manipulation with a meal of cows we could increase the proportion of unsaturated fatty acids in milk (Lock and Bauman, 2004). Indirect comparison suggests that milk fat from maize silage diets is richer in short chain FA and linoleic acids when compared to that obtained from grass silage diets. Compared to fresh grass, grass silage favours myristic and palmitic acids at the expense of mono and polyunsaturated FA, including CLA. The mechanisms for these differences are mostly unknown (Chilliard et al., 2001). Hanuš et al. (2016) concluded that breed had minor effect on the FA of milk fat and more significant factors were seasonal variability and cow feeding.

The quality and yield of cheese from various sources of milk is different. Chemical composition and cholesterol content of the 3 types of cheese were similar between breeds, whereas the cheese made with Brown Swiss milk showed greater contents of monounsaturated and polyunsaturated fatty acids with more cheese yield and different ripening times than HF (De Marchi et al., 2008). According to our results milk from Busha was of very good quality for cheese production. Milk and milk products from Busha should be produced in an environmentally friendly manner and with recognizable product designs (as cheese Skripavac made from Busha milk in Croatia) (Konjačić et al., 2004).

\section{CONCLUSION}

In conclusion, from technological point of view Simmental milk (indoors) and HF organic milk possessed advantage in comparison with HF conventional milk in regard to content of dry matter and fat (13.01, 12.83 and $12.06 \%$, respectively and $4.30,3.97$ and $3.50 \%$, respectively) and were more suitable for cheese production. Milk from autochthonous Busha breed was also convenient for cheese production because it had high content of protein and casein (3.67 and 2.63\%, respectively). Milk fat had the largest estimated coefficients of variations in all breeds, indicating the effect of nutrition on its content. Busha and HF (conventional) milk fat most varied (CV 14.01 and $10.29 \%$, respectively). In regard to hygienic parameters organic HF and Busha milk had the lowest content of SCC and CFU. Fatty acid profile was different among HF organic, conventional and Simmental milk (indoors). Organic milk had a better profile for human nutrition because contained less SFA and more MUFA and PUFA in comparison to HF conventional and Simmental (indoors) milk.

Based on this, organic production contributes to production of better milk quality, although in spite of that there is still room for further research, mostly in the cases of the milk fat and protein because of their great importance in cheese production. Agriculture directly affects biodiversity through different cultivation practices and organic production could be useful in conservation of biodiversity. Farmers have been encouraged to consider the effects of intensification on farm biodiversity and importance of biodiversity in cheese production is increasingly apparent. More data are needed at breed level and it is important to develop the knowledge base on livestock biodiversity to help to maintain local species and breeds that may otherwise become extinct.

\section{ACKNOWLEDGEMENT}

This research is a part of project supporting by Ministry of Education, Science and Technological development, Republic of Serbia, Project 31095 (2011-2017).

\section{REFERENCES}

AULDIST, M.J., JOHNSTON, K.A., WHITE, N.J., FITZSIMONS, W.P., BOLAND, M.J.: A comparison of the composition, coagulation characteristics and cheesemaking capacity of milk from Friesian and Jersey dairy cows. Journal of Dairy Research, 71:51-57, 2004.

BARBANO, D.M., RASMUSSEN, R.R., LYNCH, J.M.: Influence of milk SCC and milk age on cheese yield. Journal of Dairy Science, 74:369-388, 1991. 
BERARD, L. and MARCHENAY, P.: Local products and geographical indications: taking into account of local knowledge and biodiversity. Cultural Diversity and Biodiversity. International Social Science Journal, 187:109-116, 2006.

CHLLIARD,Y., FERLAY, A., DOREAU, M.: Effect of different types of forages, animal fat or marine oils in cow's diet on milk fat secretion and composition, especially conjugated linoleic acid (CLA) and polyunsaturated fatty acids. Livestock Production Science, 70: 31-48, 2001.

DECANTE, F.: Perception of the organic farming of livestock from the point of the view of veterinary. C. R. Academia of Agriculture France. 88(3): 25-34, 2002.

DE MARCHI, M., DAL ZOTTO, R., CASSANDRO, M., BITTANTE, G.: Milk coagulation ability of five dairy cattle breeds. Journal of Dairy Science, 90(8): 3986-3992, 2007.

DE MARCHI, M., BITTANTE, G., DAL ZOTTO, R., DALVIT, C., CASSANDRO, M.: Effect of Holstein Friesian and Brown Swiss breeds on quality of milk and cheese. Journal of Dairy Science, 91: 4092-4102, 2008.

EENENNAAM, A.V. and MEDRANO, J.F.: Milk protein polymorphisms in California dairy cattle. Journal of Dairy Science, 74: 1730-1742, 1991.

EHLERS, S. and HURT, J.: Cheeses of the World. Penguin Group (USA) Inc., New York, NY, 2008.

FAO:The Second Report on the State of the World's-Animal genetic resources for food and agriculture. FAO Commission on Genetic Resources for Food and Agriculture Assessments. 2015 Commission on Genetic Resources for Food and Agriculture. Food and Agriculture Organization of the United Nations, Rome 2015.

GERMAN, J. and DILLARD, C.: Composition, structure and adsorption of milk lipids: a source of energy, fat-soluble nutrients and bioactive molecules. Critical Review in Food Science and Nutrition, 46, 57-92, 2006.

HANUŠ, O., KRIŽOVA, L., SAMKOVA, E., ŠPICKA, J., KUCERA, J., KLIMEŠOVA, M., ROUBAL, P., JEDELSKA, R.: The effect of cattle breed, season and type of diet on the fatty acid profile of raw milk. Archives Animal Breeding, 59:373-380, 2016.

HARMON, R.J.: Somatic cell counts: a primer. National Mastitis Council Annual Meeting Proceedings. 40th Annual Meeting, Feb 11-14, 2001 Reno, NV, pp. 3-9.

HOLE, D.G., PERKINS, A.J., WILSON, J.D., ALEXANDER, I.H., GRICE, P.V., EVANS, A.D.: Does organic farming benefit biodiversity? Biological Conservation, 122: 113-130, 2005.

JENKINS, T.C. and McGUIRE, M.A.: Major Advances in Nutrition: Impact on Milk Compositio. Journal of Dairy Sciences, 89:1302-1310, 2006.

KOHLER-ROLLEFSON, I.: Community-Based Management of Animal Genetic Resources - with Special Reference to Pastoralists-Ilse Community-based management of animal genetic resource. Proceedings of the workshop held in Mbabane, Swaziland, 7-11 May 2001, pp. 13-27.

KONJAČIĆ, M., IVANKOVIĆ, A., CAPUT, P., MIJIĆ, P., PRANIĆ, D.: Buša u Hrvatskoj. Stočarstvo 58(3):163-177, 2004.

LAWRENCE, R.C.: Cheeses yield potential of milk. Pages 109-120 in Factors Affecting the Yield of Cheese. D.B. Emmons, ed. IDF Special Issue No. 9301, International Dairy Federation, Brussels, Belgium, 1991.

LOCK, A.L. and BAUMAN, D.E.: Modifying milk fat composition of dairy cows to enhance fatty acids beneficial to human health. Lipids, 39: 1197-1206, 2004.

MONDELAERS, K., AERTSENS, J., VAN HUYLEBROECK, G.: “A meta-analysis of the differences in environmental impacts between organic and conventional farming”. British Food Journal, 111(10): 1099-120, 2009.

NIGGLI, U., FLIESSBACHl, A., HEPPERLY, P., SCIALABBA, N.: Low Greenhouse Gas Agriculture: Mitigation and Adaption Potential of Sustainable Farming Systems, ROME, FAO, 2008.

PEREZ, A. J. (2011): Production systems, technical parameters and quality of bovine milk producers in southern Chile. Ciencia e Investigacion Agraria, 38(1),15-21, 2011.

QUIST, M., LeBLANC, S., HAND, K., LAZENBY, D., MIGLIOR, F., KELTON, D.: Milking-to-milking variability for milk yield, fat and protein percentage, and somatic cell count. Journal of Dairy Science, 91 (9): 3412-3423, 2008.

RAHMANN, G.: (2011): Biodiversity and Organic farming: What do we know? LandbauforschungvTIAgriculture and Forestry Research, 3 (61): 189-208, 2011.

RUEGG, P. L.: Practical Food Safety interventions for dairy production. Journal of Dairy Science, 86: 1-9, 2002.

SAMKOVA, E., SPICKA, J., PESEK, M., PELIKANOVA, T., HANUS, O.: Animal factors affecting fatty acid composition of cow milk fat: a review. South African Journal of Animal Science, 42 (2): 83-100, 2012.

SERBIAN REGULATIONS. Regulations on the quality of raw milk. Official Gazette of the Republic of Serbia 21/2009, 2009.

SOYEURT, H. and GENGLER, N.: Genetic variability of fatty acids in bovine milk. Biotechnological Agronomy, Society and Environment, 12(2): 203-210, 2008.

WIKING, L., THEIL, P.K., NIELSEN, J.H., SORENSEN, M.T.: Effect of grazing fresh legumes or feeding silage on fatty acids and enzymes involved in the synthesis of milk fat in dairy cows. Journal of Dairy Research, 77(3): 337-342, 2010. 


\title{
UTICAJ ORGANSKE POLJOPRIVREDE NA OČUVANJE BIODIVERZITETA I KVALITET MLEKA ZA TRADICIONALNU PROIZVODNJU SIRA
}

\author{
Anka POPOVIĆ-VRANJEŠ, Snežana PASKAŠ, Zsolt BECSKEI, Marija JEVTIĆ, Saša KRSTOVIĆ
}

Izvod: Organska poljoprivreda predstavlja poljoprivrednu praksu koja može doprineti očuvanju biološke raznovrsnosti kao i uzgoju krava sa najpoželjnijim osobinama mleka. Sastav mleka se može razlikovati u zavisnosti od genetičke raznolikosti životinja i različitih sistema ishrane. Ovo se odnosi na veći sadržaj suve materije, masti, proteina i povoljniji odnos zasićenih/nezasićenih masnih kiselina, što je veoma bitno u tradicionalnoj proizvodnji sira. U radu su izvršene standardne hemijske analize i prikazane su razlike u hemijskim osobinama mleka i profilu masnih kiselina u zavisnosti od pripadnosti različitoj rasi i različitom načinu uzgoja životinja. Mleko Simentalske rase (štalski uzgoj) je posedovalo najveći sadržaj suve materije i masti (13,01 i 4,30\%, pojedinačno), dok je sadržaj proteina i kazeina bio najviši u mleku Buše (3,67 i 2,63\%, pojedinačno). Mleko Holštajn-Frizijske rase iz organskog uzgoja je posedovalo ujednačeniji sastav i manje varijacije u sastavu mleka i zajedno sa mlekom Buše odgovarajući higijenski kvalitet mleka (nizak nivo broja ukupnih bakterija i somatskih ćelija u mleku). Takođe, u nutritivnom pogledu mleko Holštajn-Frizijske rase iz organskog uzgoja je posedovalo poželjniji profil masnih kiselina i raspolagalo je sa: zasićenim masnim kiselinama $(63,40 \%)$, mononezasićenim $(30,79 \%)$ i polinezasićenim $(5,72 \%)$. Istovremeno, mleko Holštajn-Frizijske rase iz konvencionalnog uzgoja je posedovalo : zasićenih masnih kiselina (67,45\%), mononezasićenih $(29,27 \%)$ i polinezasićenih (3,28\%), dok je mleko Simentalske rase (štalski uzgoj) posedovalo najviši sadržaj zasićenih $(71,21 \%)$ i manji mononezasićenih $(25,39 \%)$ i polinezasićenih masnih kiselina $(3,40 \%)$. Postoje različiti načini očuvanja biodiverziteta a primena standarda organske proizvodnje u tradicionalnoj proizvodnji sira može doprineti dobijanju sigurnijih, kvalitetnijih proizvoda koji su više prepoznatljivi na tržištu.

Ključne reči: biodiverzitet, organska poljoprivreda, rase, kvalitet mleka, sir

Received / Primljen: 18.10.2017. Accepted / Prihvaćen: 24.12.2017. 